\title{
Korelacja parametrów charakteryzujących strukturę porową kamieni cementowych badanych za pomocą porozymetrii rtęciowej oraz mikrotomografii komputerowej
}

\begin{abstract}
Zastosowanie zaczynów cementowych typu Gasblok do uszczelniania przestrzeni pierścieniowej w otworze wiertniczym ma na celu wyeliminowanie możliwości tworzenia się mikronieszczelności w strukturze płaszcza cementowego. Jakość stwardniałego zaczynu cementowego możliwa jest do określenia poprzez analizę parametrów uzyskanych z badań porozymetrycznych oraz mikrotomograficznych. Porozymetr AutoPore umożliwia przeprowadzenie badań mikrostruktury porowej próbek oraz określenie ich przepuszczalności, natomiast mikrotomograf rentgenowski Benchtop pozwala na wyznaczenie rozkładu przestrzennego porów oraz na ich wizualizację. Połączenie tych dwóch metod badawczych umożliwia dokonanie modyfikacji receptur lub zaprojektowanie nowego składu zaczynu, który po związaniu będzie się charakteryzował jednolitą mikrostrukturą o niskiej porowatości i przepuszczalności. Wyniki prowadzonych prac przyczyniają się do zaprojektowania składu zaczynu uniemożliwiającego przechodzenie gazu przez strukturę płaszcza cementowego, co zostało omówione w niniejszej publikacji.
\end{abstract}

Słowa kluczowe: mikrotomografia, porowatość, korelacja, zaczyn cementowy, stwardniały zaczyn cementowy, płaszcz cementowy, mikrostruktura, porozymetria.

\section{Correlation of parameters describing the pore structure of set cement by using mercury porosimetry and X-ray microtomography}

\begin{abstract}
Use of Gasblok type cement slurries for sealing the annular space in the borehole, is intended to eliminate the possibility of the formation of microleaks in the structure of the cement sheath. The quality of the set cement slurry can be determined by analyzing the parameters obtained from porosimetric and X-ray microtomography studies. The AutoPore porosimeter enables testing of the pore microstructure of samples and determine their permeability. The Benchtop X-ray microtomograph allows to determine the spatial distribution of pores and their visualization. Combining these two methods allows recipe modification or development of new slurry composition, which will be characterized by a uniform microstructure of low porosity and permeability. The results contribute to the design of a slurry composition, which prevents gas migration through the structure of the cement sheath.
\end{abstract}

Key words: X-ray microtomography, porosity, correlation, slurry, set cement, cement sheath, microstructure, porosimetry.

\section{Badania struktury porowej stwardniałych zaczynów cementowych}

Zaczyn cementowy podczas hydratacji przechodzi ze stanu ciekłego poprzez żelowy do stanu stałego. Po zakończeniu procesu wiązania w mikrostrukturze stwardniałego zaczynu widoczne są puste przestrzenie, które połączone są ze sobą, tworząc rozległą nieregularną siatkę $[1,2,4,6,7]$. W celu dokonania ich analizy ilościowej oraz jakościowej prowadzi się badania mikrostruktury porowej za pomocą nowoczesnych me- tod badawczych. Na podstawie uzyskanych wyników oraz ich interpretacji możliwe jest przeprowadzenie modyfikacji składu zaczynu, skutkującej otrzymaniem receptury stwardniałego zaczynu o obniżonej porowatości oraz bardziej szczelnej matrycy płaszcza cementowego $[9,11,12]$. Poniżej krótko scharakteryzowano dwie metody badania struktury porowej oraz dokonana została korelacja uzyskanych wyników badań. 


\section{Porozymetria rtęciowa}

Badania struktury porowej próbek stwardniałych zaczynów prowadzone są za pomocą porozymetru rtęciowego $\mathrm{Au}-$ toPore IV 9500 (fotografia 1). Parametryzację przestrzeni porowych uzyskuje się na podstawie pomiarów krzywych ciśnień kapilarnych. Pomiar oparty jest na wyznaczeniu zależności pomiędzy wielkością ciśnienia kapilarnego oraz wielkością promienia gardzieli, a także kształtem oraz sieciami wzajemnych połączeń porów o zróżnicowanych promieniach $[8,10,15,16]$. Porozymetr AutoPore umożliwia nakreślenie krzywych kumulacyjnych (intruzji oraz ekstruzji rtęci w strukturę porową próbki). Kształt krzywej ekstruzji (dla ciśnień malejących) jest podstawowym źródłem informacji o wielkości odstępstwa realnej przestrzeni porowej od modelu walcowego $[3,13,14]$. Po dokonaniu analizy oraz interpretacji uzyskanych wyników badań porozymetrycznych (głównie wielkości liczonych na podstawie krzywych ciśnień kapilarnych) otrzymujemy następujące parametry opisujące strukturę próbki:

- całkowitą objętość porów,

- porowatość zliczoną z porozymetru,

- wielkość średniej kapilary,

- powierzchnię właściwą,

- gęstość próbek (objętościową i szkieletową),

- procentowy udział porów o poszczególnych średnicach,

- dodatkowo na podstawie ciśnienia progowego możliwe jest określenie średnicy progowej [5].

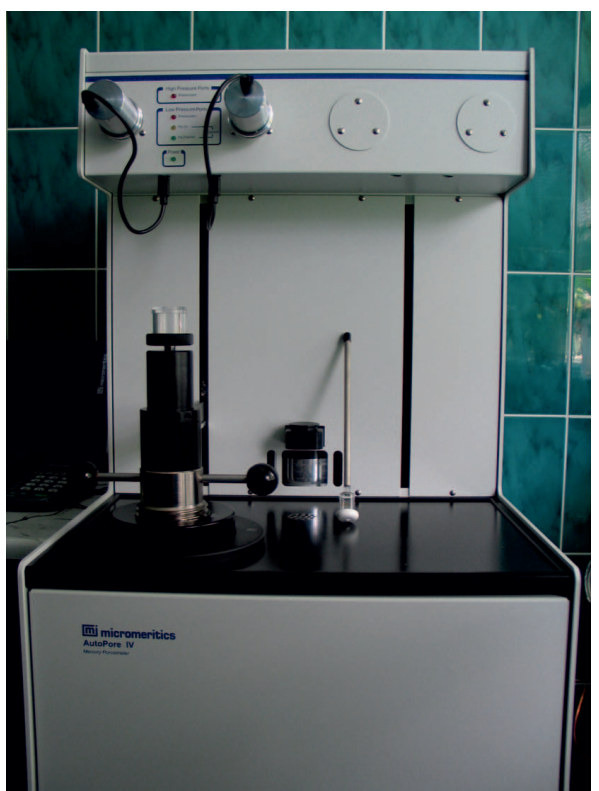

Fot. 1. Porozymetr AutoPore IV 9500

Na podstawie pomiaru objętości rtęci wnikającej do przestrzeni porowej badanego materiału program umożliwia przedstawienie objętości porów otwartych w zależności od przyłożo- nego ciśnienia. Rozmiar porów odpowiada określonym wartościom ciśnienia i obliczany jest $\mathrm{z}$ wykorzystaniem wzoru Washburna $[5,13,14]$. Na tej podstawie możliwe jest przedstawienie rozkładu porów w zależności od ich rozmiarów (uzależnionych od ciśnienia wypełniającej rtęci) - rysunek 1 . Ze względu na duży rozrzut wielkości ciśnienia (rozmiaru porów) wyniki prezentowane są w układzie logarytmicznym w skali odwróconej, czyli od wartości największych do najmniejszych.

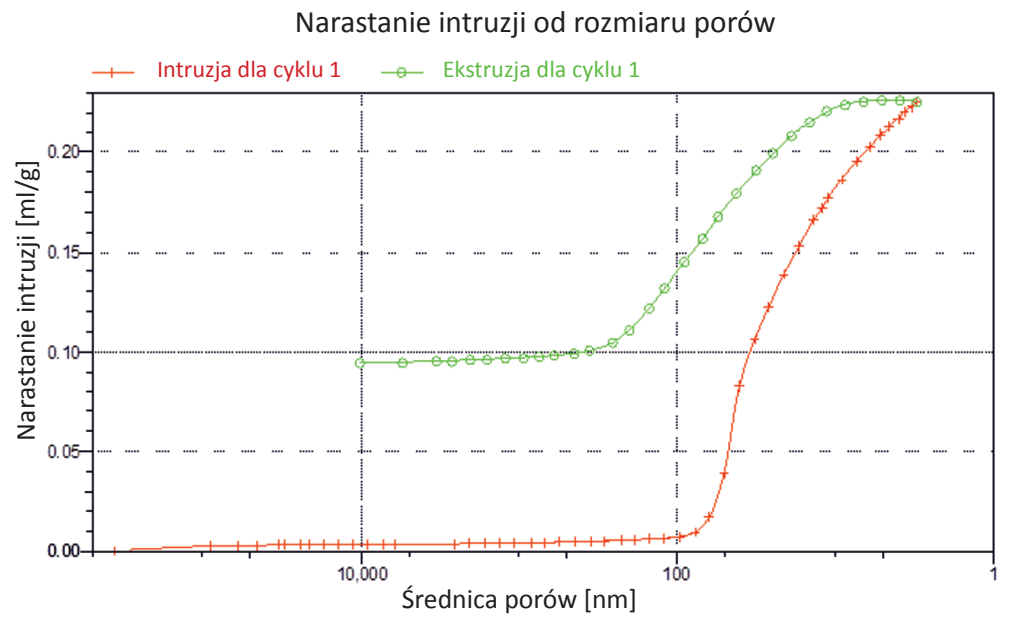

Rys. 1. Rozkład porów w zależności od rozmiarów (przyłożonego ciśnienia)

\section{Mikrotomografia rentgenowska}

Badania mikrostruktury wykonywane przy użyciu mikrotomografu rentgenowskiego Benchtop 160Xi CT (fotografia 2) umożliwiają przeprowadzenie wizualizacji struktury próbki stwardniałego zaczynu cementowego. Prześwietlenie kamienia cementowego za pomocą promieni $\mathrm{X}$ pozwala na trójwymiarowe przedstawienie obrazu przestrzeni porowej wewnątrz badanej próbki $[3,15]$. Po przetworzeniu trójwymiarowego obrazu możliwe jest uzyskanie różnego rodzaju informacji dotyczących porowatości, liczby i wielkości niepołączonych obiektów, współczynnika krętości oraz wpływu tych cech na przepuszczalność kamienia cementowego. Podczas badań przy użyciu mikrotomografii rentgenowskiej (micro-CT) mierzony jest głównie współczynnik thumienia liniowego $\mu$. Definiowany jest on przez prawo Bouguera (Lamberta):

$$
I / I_{0}=\exp (-\mu h)
$$

gdzie:

$I_{0}$ - natężenie promieniowania padającego,

$I$ - natężenie promieniowania X po przejściu przez ośrodek, $h$ - grubość próbki,

$\mu$ - współczynnik tłumienia liniowego.

Prawo Bouguera (Lamberta) zakłada, iż wiązka posiada równoległe promienie, fala jest płaska i występuje monochromatyczne źródło promieni X (o jednej częstotliwości i dłu- 


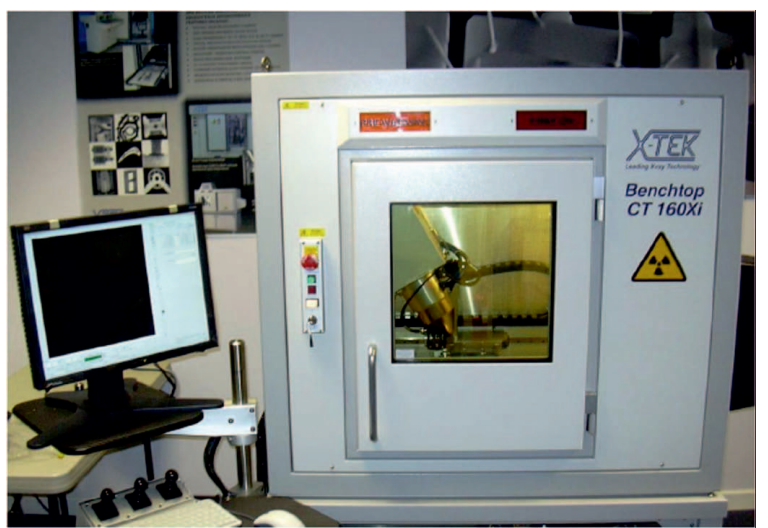

Fot. 2. Mikrotomograf rentgenowski Benchtop CT 160Xi

gości fali). Jednak stosowana w skanerach micro-CT lampa rentgenowska emituje widmo energii promieniowania $\mathrm{X}$, dlatego też niezbędne jest zastosowanie całki $\mu$ po drodze optycznej promieniowania. Dodatkowo podczas badań kamieni cementowych za pomocą mikrotomografii rentgenowskiej przyjmuje się, iż są to materiały niejednorodne $[3,15]$.
Komputerowa mikrotomografia rentgenowska polega na zapisywaniu promieniowania $X$ przechodzącego przez próbkę przy kolejnych pozycjach kątowych w zakresie $0 \div 360^{\circ}$. Kolejnym etapem jest wykorzystanie algorytmu projekcji wstecznej w celu utworzenia rekonstrukcji wirtualnego przekroju przez badaną próbkę. W efekcie uzyskuje się zobrazowanie zmienności współczynnika pochłaniania liniowego. W trakcie obracania badanej próbki odtwarzane są obrazy 3D otrzymane z sekwencyjnych warstw przekrojowych. Po zebraniu kompletnych danych 3D możliwe jest przeglądanie dowolnej płaszczyzny badanego obiektu $[3,15,16]$.

Tworzenie obrazu przestrzennego 3D za pomocą mikrotomografu rentgenowskiego można podzielić na trzy etapy: rejestrację projekcji, rekonstrukcję obrazu oraz przetwarzanie danych. Następnie wykonywana jest analiza struktury porowej na podstawie obliczeń w programie MAVI 1.3.1. Na tym etapie badania zostaje dokonany podział struktury porowej ze względu na objętość według tablicy $1[3,16]$.

Tablica 1. Podział struktury porowej ze względu na objętość izolowanych obiektów

\begin{tabular}{|c|c|c|c|c|c|c|}
\hline $\begin{array}{c}\text { Objętość } \\
{[\text { woksel }]}\end{array}$ & $1-9$ & $10-99$ & $100-999$ & $1000-9999$ & $10000-99999$ & $>100000$ \\
\hline $\begin{array}{c}\text { Objętość } \\
{\left[\mu \mathrm{m}^{3}\right]}\end{array}$ & $2 \cdot 10^{2}-2 \cdot 10^{3}$ & $2 \cdot 10^{3}-2 \cdot 10^{4}$ & $2 \cdot 10^{4}-2 \cdot 10^{5}$ & $2 \cdot 10^{5}-2 \cdot 10^{6}$ & $2 \cdot 10^{6}-2 \cdot 10^{7}$ & $>2 \cdot 10^{7}$ \\
\hline Klasa & I & II & III & IV & V & VI \\
\hline Kolor & źółty & niebieski & czerwony & zielony & biały & fioletowy \\
\hline
\end{tabular}

\section{Badania laboratoryjne}

Badania laboratoryjne świeżych zaczynów uszczelniających przeprowadzono zgodnie z normami: PN-EN ISO 10426-2 Przemyst naftowy i gazowniczy. Cementy $i$ materiaty do cementowania otworów. Czesść 2: Badania cementów wiertniczych oraz API SPEC 10 Specification for materials and testing for well cements. Natomiast badania mikrostruktury porowej stwardniałych zaczynów cementowych wykonano za pomocą:

- porozymetru rtęciowego AutoPore IV 9500 (fotografia 1)

- współczynnik porowatości porozymetrycznej, procentowy udział porów należących do poszczególnych zakresów średnic,

- mikrotomografu rentgenowskiego Benchtop 160Xi CT (fotografia 2) - współczynnik porowatości mikrotomograficznej, wizualizacja struktury porowej oraz ilość i udział porów należących do danej klasy objętościowej.

Analizując składy zaprojektowanych zaczynów, dokonano wyboru 4 receptur o zbliżonych parametrach oznaczanych dla świeżych zaczynów. Wodą zarobową do sporządzenia próbek była woda wodociągowa. Zaczyn nr 1 to recep- tura z dodatkiem lateksu i 15\% mikrocementu, mającego za zadanie doszczelnienie matrycy cementowej. Skład nr 2 zawierał $10 \%$ mikrosfery, mającej na celu obniżenie gęstości zaczynu (zastosowano w nim również 20-procentową ilość dodatku mikrocementu). W trzecim składzie zawartość mikrocementu również wynosiła $20 \%$, natomiast zwiększono ilość mikrosfery z $10 \%$ na $20 \%$. Receptura nr 4 posiadała tylko 5\% mikrocementu, a lateks zastąpiony został 6,5-procentową ilością środka antymigracyjnego GS ${ }^{1}$. Składy zaczynów zestawiono w tablicy 2. Badania zaczynów przeznaczonych do uszczelniania kolumn rur okładzinowych wykonano dla warunków otworowych odpowiadających temperaturze $40^{\circ} \mathrm{C}$ oraz ciśnieniu $15 \mathrm{MPa}$. Świeże zaczyny 1 i 4 oraz 2 i 3 posiadały porównywalne parametry (tablica 3 ). Z zaczynów sporządzone zostały próbki stwardniałych zaczy-

${ }^{1} \mathrm{GS}$ - wielkocząsteczkowy kopolimer używany w celu wyeliminowania ewentualności przepływu gazu przez wiążący zaczyn cementowy. 
Tablica 2. Składy zaczynów wytypowanych do badań

\begin{tabular}{|l|c|c|c|c|}
\hline Receptura $\mathrm{nr}$ & 1 & 2 & 3 & 4 \\
\hline Woda wodociągowa & $\mathrm{w} / \mathrm{c}=0,52$ & $\mathrm{w} / \mathrm{c}=0,53$ & $\mathrm{w} / \mathrm{c}=0,60$ & $\mathrm{w} / \mathrm{c}=0,50$ \\
\hline Bentonit & - & $0,3 \%$ & $0,3 \%$ & - \\
\hline Dodatek odpieniający & $1,0 \%$ & $0,5 \%$ & $0,5 \%$ & $0,2 \%$ \\
\hline Dodatek upłynniający & $0,1 \%$ & $0,1 \%$ & $0,15 \%$ & $0,4 \%$ \\
\hline Dodatek antyfiltracyjny & $0,2 \%$ & $0,25 \%$ & $0,25 \%$ & - \\
\hline${\text { Lateks/ }{ }^{\prime} \mathrm{GS}}$ & $10,0 \%$ & $10,0 \%$ & $10,0 \%$ & ${ }^{*} 6,5 \%$ \\
\hline Stabilizator lateksu & $2,0 \%$ & $2,0 \%$ & $2,0 \%$ & - \\
\hline Dodatek przyspieszający/opóźniający ${ }^{*}$ czas gęstnienia & $1,5 \%$ & - & ${ }^{*} 0,1 \%$ & $1,0 \%$ \\
\hline Mikrocement & $15,0 \%$ & $20,0 \%$ & $20,0 \%$ & $5,0 \%$ \\
\hline Mikrosfera & - & $10,0 \%$ & $20,0 \%$ & - \\
\hline Cement CEM I 32,5 R & $100,0 \%$ & $100,0 \%$ & $100,0 \%$ & $100,0 \%$ \\
\hline Dodatek spęczniający & $0,3 \%$ & $0,3 \%$ & $0,3 \%$ & $0,1 \%$ \\
\hline
\end{tabular}

Oznaczenia: w/c - współczynnik wodno-cementowy.

nów cementowych, które hydratyzowały 28 dni w warunkach otworopodobnych (temperatura $40^{\circ} \mathrm{C}$, ciśnienie $15 \mathrm{MPa})$.

Następnym etapem było przeprowadzenie badań mikrostruktury z uzyskanych stwardniałych zaczynów cementowych (porozymetria rtęciowa oraz mikrotomografia rentgenowska, tablica 4). Wyniki badań mikrostruktury porowej zostały poddane analizie porównawczej (tablica 5).
Tablica 3. Parametry świeżych zaczynów

\begin{tabular}{|c|c|c|c|c|c|}
\hline \multirow{2}{*}{\multicolumn{2}{|c|}{ Parametr }} & \multicolumn{4}{|c|}{ Skład nr } \\
\hline & & 1 & 2 & 3 & 4 \\
\hline \multicolumn{2}{|l|}{ Gęstość $\left[\mathrm{g} / \mathrm{cm}^{3}\right]$} & 1,79 & 1,64 & 1,49 & 1,80 \\
\hline \multicolumn{2}{|l|}{ Rozlewność [mm] } & 290 & 275 & 280 & 260 \\
\hline \multicolumn{2}{|l|}{ Filtracja ${ }^{*}\left[\mathrm{~cm}^{3} / 30 \mathrm{~min}\right]$} & 48,0 & 3,6 & 4,0 & 11,0 \\
\hline \multicolumn{2}{|l|}{ Lepkość plastyczna $[\mathrm{mPa} \cdot \mathrm{s}]$} & 70,5 & 69,0 & 78,0 & 112,5 \\
\hline \multicolumn{2}{|l|}{ Granica płynięcia $[\mathrm{Pa}]$} & 5,3 & 9,1 & 3,8 & 8,4 \\
\hline \multirow{2}{*}{ Czas gęstnienia $^{*}$ [godz.:min] } & $30 \mathrm{Bc}$ & $2: 14$ & 2:02 & $2: 45$ & $2: 42$ \\
\hline & $100 \mathrm{Bc}$ & $2: 37$ & $2: 44$ & $3: 03$ & $4: 24$ \\
\hline
\end{tabular}

* Badanie dla temperatury $40^{\circ} \mathrm{C}$, ciśnienie $15 \mathrm{MPa}$.

Tablica 4. Parametry opisujące mikrostrukturę stwardniałych zaczynów badanych za pomocą porozymetru rtęciowego

\begin{tabular}{|c|c|c|c|c|c|c|c|}
\hline \multirow{2}{*}{$\begin{array}{l}\text { Zaczyn } \\
\text { numer }\end{array}$} & \multirow{2}{*}{$\begin{array}{l}\text { Warunki } \\
\text { hydratacji } \\
\text { temp. ciśn. }\end{array}$} & \multirow{2}{*}{$\begin{array}{c}\text { Porowatość } \\
{[\%]} \\
\text { (porozymetria } \\
\text { rtęciowa) }\end{array}$} & \multicolumn{5}{|c|}{$\begin{array}{l}\text { Procentowy udział ilości poszczególnych porów o zakresie średnic } \\
\text { (suma wszystkich przedziałów jest równa 100\%) }\end{array}$} \\
\hline & & & $>1 \mu \mathrm{m}$ & $1,0 \div 0,1 \mu \mathrm{m}$ & $0,1 \div 0,05 \mu \mathrm{m}$ & $0,05 \div 0,01 \mu \mathrm{m}$ & $<0,01 \mu \mathrm{m}$ \\
\hline 1 & \multirow{4}{*}{$\begin{array}{l}40^{\circ} \mathrm{C} \\
15 \mathrm{MPa}\end{array}$} & 37,04 & 1,61 & 1,28 & 6,00 & 36,89 & 54,20 \\
\hline 2 & & 38,35 & 2,50 & 2,64 & 3,31 & 37,31 & 54,21 \\
\hline 3 & & 41,16 & 1,68 & 1,58 & 2,41 & 39,81 & 54,49 \\
\hline 4 & & 33,50 & 2,36 & 2,09 & 7,50 & 35,64 & 52,39 \\
\hline
\end{tabular}

Mikrotomografia rentgenowska umożliwia odczytanie wielu parametrów opisujących mikrostrukturę badanej próbki. Po przeprowadzeniu badań otrzymujemy dane dotyczące liczby podgrup należących do danej klasy objętościowej, objętość tej klasy w wokselach oraz udział procentowy klasy obliczony z objętości. Na podstawie wykonanej analizy korelacyjnej stwierdzono, że porównanie takiego parametru jak udział procentowy liczby podgrup uzyskanych podczas badania za pomocą mikrotomografu (obliczony z liczby podgrup w klasie) umożliwia skorelowanie tego parametru z procentowym udziałem ilości porów badanych za pomocą porozymetrii rtęciowej. Stwierdzono, iż wykonując korelację pozostałych parametrów opisujących mikrostrukturę stwardniałych zaczynów za pomocą obydwu metod, uzyskuje się niskie wartości współczynnika regresji.

\section{Korelacja wyników badań}

Analizie porównawczej poddane zostały przestrzenie porowe o zakresach od największej średnicy $(>1 \mu \mathrm{m})$ oraz od największej objętości (klasa VI), czyli od maksymalnego za- 
Tablica 5. Parametry opisujące mikrostrukturę stwardniałych zaczynów badanych za pomocą mikrotomografu rentgenowskiego

\begin{tabular}{|c|c|c|c|c|c|c|c|c|}
\hline \multirow{3}{*}{$\begin{array}{l}\text { Zaczyn } \\
\text { numer }\end{array}$} & \multirow{3}{*}{$\begin{array}{l}\text { Warunki } \\
\text { hydratacji } \\
\text { temp. ciśn. }\end{array}$} & \multirow{3}{*}{$\begin{array}{c}\text { Porowatość } \\
{[\%]} \\
\text { (mikrotomografia } \\
\text { rentgenowska) }\end{array}$} & \multicolumn{6}{|c|}{ Liczba podgrup w klasie } \\
\hline & & & $\begin{array}{c}>2 \cdot 10^{7} \\
\mu \mathrm{m}^{3}\end{array}$ & $\begin{array}{c}2 \cdot 10^{6}-2 \cdot 10^{7} \\
\mu \mathrm{m}^{3}\end{array}$ & $\begin{array}{c}2 \cdot 10^{5}-2 \cdot 10^{6} \\
\mu \mathrm{m}^{3}\end{array}$ & $\begin{array}{c}2 \cdot 10^{4}-2 \cdot 10^{5} \\
\mu \mathrm{m}^{3}\end{array}$ & $\begin{array}{c}2 \cdot 10^{3}-2 \cdot 10^{4} \\
\mu \mathrm{m}^{3}\end{array}$ & $\begin{array}{c}2 \cdot 10^{2}-2 \cdot 10^{3} \\
\mu \mathrm{m}^{3}\end{array}$ \\
\hline & & & VI & $\mathrm{V}$ & IV & III & II & I \\
\hline 1 & \multirow{9}{*}{$\begin{array}{c}40^{\circ} \mathrm{C} \\
15 \mathrm{MPa}\end{array}$} & 7,6 & 1 & 12 & 415 & 8327 & 78508 & 9874 \\
\hline 2 & & 15,4 & 1 & 8 & 125 & 2551 & 50115 & 7616 \\
\hline 3 & & 22,1 & 1 & 5 & 127 & 767 & 23708 & 20161 \\
\hline 4 & & 8,4 & 3 & 10 & 448 & 6621 & 66730 & 40420 \\
\hline & & - & \multicolumn{6}{|c|}{ (udział procentowy liczby podgrup należących do danej klasy objętościowej) } \\
\hline 1 & & 7,6 & 0,00 & 0,01 & 0,43 & 8,57 & 80,82 & 10,17 \\
\hline 2 & & 15,4 & 0,00 & 0,01 & 0,21 & 4,22 & 82,95 & 12,61 \\
\hline 3 & & 22,1 & 0,00 & 0,01 & 0,28 & 1,71 & 52,96 & 45,03 \\
\hline 4 & & 8,4 & 0,00 & 0,01 & 0,39 & 5,80 & 58,42 & 35,38 \\
\hline
\end{tabular}

kresu pomiarowego danego urządzenia do minimalnego. Wyboru takiego dokonano z uwagi na zakres pomiarowy metod badawczych (rysunek 2). Porozymetria rtęciowa umożliwia pomiar porów od $0,001 \mu \mathrm{m}$. Natomiast podczas badania mikrostruktury porowej za pomocą mikrotomografu rentgenowskiego przestrzenie porowe określane są za pomocą wokseli (sześcian o boku 5,7 $\mu \mathrm{m}$ ). W związku z powyższym korelacja najmniejszych przestrzeni porowych nie może być przeprowadzona, ponieważ mikrotomograf ich nie rozpoznaje.

Podczas analizy wyników uzyskanych z poszczególnych metod badawczych dokonano podstawowej korelacji przy użyciu współczynnika Pearsona. Jest on wykorzystywany do badania związków prostoliniowych zmienności, w których zmiana jednych wartości skutkuje proporcjonalną zmianą średnich wartości drugiej cechy. Współczynnik korelacji Pearsona obliczono na podstawie wzoru (2):

$$
r_{x, y}=\frac{\operatorname{cov}(x, y)}{S d_{x} \cdot S d_{y}}
$$

Różnice w zakresie pomiarowym porowatości

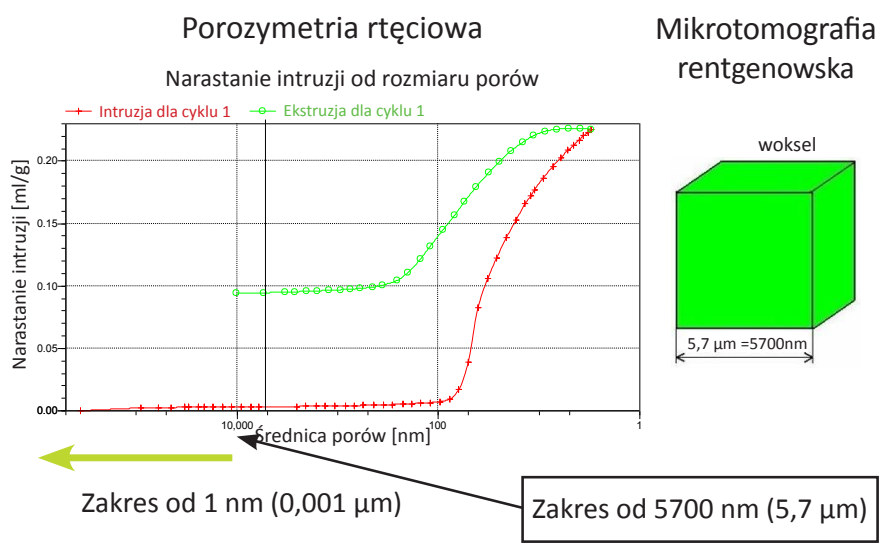

Rys. 2. Różnice w zakresie pomiarowym porozymetrii rtęciowej

\section{Interpretacja siły związków korelacyjnych}

Współczynnik korelacji Pearsona:

- poniżej 0,2 - korelacja słaba (praktycznie brak związku),

- $0,2 \div 0,4-$ korelacja niska (zależność wyraźna),

- $0,4 \div 0,6$ - korelacja umiarkowana (zależność istotna),

- 0,6 $\div 0,8$ - korelacja wysoka (zależność znaczna),

- $0,8 \div 0,9$ - korelacja bardzo wysoka (zależność bardzo duża),

- $\quad 0,9 \div 1,0$ - korelacja całkowita (zależność praktycznie pełna). Na początku obliczono kowariancję (3), która określa zależność liniową między zmiennymi losowymi $x$ i $y$, oraz estymator największej wiarygodności $S d_{x}, S d_{y}$ (4), (5), dający najmniejsze wartości odchyleń:

$$
\begin{aligned}
\operatorname{cov}(x, y) & =\frac{\sum\left(x_{i}-\bar{x}\right)\left(y_{i}-\bar{y}\right)}{n} \\
S d_{x} & =\sqrt{\frac{\sum\left(x_{i}-\bar{x}\right)^{2}}{n}} \\
S d_{y} & =\sqrt{\frac{\sum\left(y_{i}-\bar{y}\right)^{2}}{n}}
\end{aligned}
$$

gdzie:

$x$ - procentowe udziały objętości poszczególnych porów,

$\bar{x}$ - procentowe udziały objętości poszczególnych porów (wartość średnia),

$y$ - procentowe udziały liczby podgrup należących do danych klas objętościowych,

$\bar{y}$ - procentowe udziały liczby podgrup należących do danych klas objętościowych (wartość średnia),

$n$ - liczba prób.

Na podstawie powyższego obliczono wskaźnik determinacji liniowej (6) informujący o procencie liniowej zależności pomiędzy zmiennymi zależną i niezależną. 


$$
W D=r_{x y}^{2} \cdot 100 \%
$$

- $\quad$ wartości średnie: $\bar{x}=20,0 ; \bar{y}=14,8$

- po podstawieniu do wzorów:

$$
\begin{gathered}
\operatorname{cov}(x, y)=\frac{9644,395}{20}=482,21976 \\
S d_{x}=\sqrt{\frac{9343,911}{20}}=21,67 \\
S d_{y}=\sqrt{\frac{15353,998}{20}}=27,71 \\
r_{x, y}=\frac{482,2198}{21,67 \cdot 27,71}=0,80519 \\
r=0,81 \in<0,8 ; 0,8) \\
W D=(0,80519)^{2} \cdot 100 \% \\
\underline{W D=64,8 \%}
\end{gathered}
$$

$\mathrm{Na}$ podstawie analizy korelacyjnej stwierdza się bardzo wysoką dodatnią korelację pomiędzy analizowanymi cechami. Wzrostowi procentowego udziału objętości porów o okre- ślonej objętości zbadanej za pomocą porozymetru rtęciowego towarzyszy wzrost udziału procentowego liczby podgrup należących do danej klasy objętościowej zbadanej za pomocą mi-

\begin{tabular}{|c|c|c|c|c|c|c|c|}
\hline Lp. & $x_{i}$ & $y_{i}$ & $\left(x_{i}-\bar{x}\right)$ & $\left(y_{i}-\bar{y}\right)$ & $\left(x_{i}-\bar{x}\right)\left(y_{i}-\bar{y}\right)$ & $\left(x_{i}-\bar{x}\right)^{2}$ & $\left(y_{i}-\bar{y}\right)^{2}$ \\
\hline 1 & 1,61 & 0,00 & $-18,4$ & $-14,8$ & 272,83 & 338,01 & 220,23 \\
\hline 2 & 2,50 & 0,00 & $-17,5$ & $-14,8$ & 259,63 & 306,08 & 220,23 \\
\hline 3 & 1,68 & 0,00 & $-18,3$ & $-14,8$ & 271,79 & 335,44 & 220,23 \\
\hline 4 & 2,36 & 0,00 & $-17,6$ & $-14,8$ & 261,70 & 310,99 & 220,23 \\
\hline 5 & 1,28 & 0,01 & $-18,7$ & $-14,8$ & 277,54 & 350,25 & 219,93 \\
\hline 6 & 2,64 & 0,01 & $-17,4$ & $-14,8$ & 257,37 & 301,20 & 219,93 \\
\hline 7 & 1,58 & 0,01 & $-18,4$ & $-14,8$ & 273,09 & 339,11 & 219,93 \\
\hline 8 & 2,09 & 0,01 & $-17,9$ & $-14,8$ & 265,53 & 320,59 & 219,93 \\
\hline 9 & 6,00 & 0,43 & $-14,0$ & $-14,4$ & 201,67 & 195,86 & 207,65 \\
\hline 10 & 3,31 & 0,21 & $-16,7$ & $-14,6$ & 244,10 & 278,39 & 214,04 \\
\hline 11 & 2,41 & 0,28 & $-17,6$ & $-14,6$ & 256,04 & 309,23 & 211,99 \\
\hline 12 & 7,50 & 0,39 & $-12,5$ & $-14,5$ & 180,55 & 156,13 & 208,80 \\
\hline 13 & 36,89 & 8,57 & 16,9 & $-6,3$ & $-105,93$ & 285,44 & 39,31 \\
\hline 14 & 37,31 & 4,22 & 17,3 & $-10,6$ & $-183,89$ & 299,81 & 112,78 \\
\hline 15 & 39,81 & 1,71 & 19,8 & $-13,1$ & $-260,17$ & 392,63 & 172,40 \\
\hline 16 & 35,64 & 5,80 & 15,6 & $-9,0$ & $-141,43$ & 244,77 & 81,72 \\
\hline 17 & 54,20 & 80,82 & 34,2 & 66,0 & 2256,85 & 1169,98 & 4353,36 \\
\hline 18 & 54,21 & 82,95 & 34,2 & 68,1 & 2330,38 & 1170,67 & 4638,97 \\
\hline 19 & 54,49 & 52,96 & 34,5 & 38,1 & 1314,95 & 1189,91 & 1453,13 \\
\hline \multirow[t]{2}{*}{20} & 52,39 & 58,42 & 32,4 & 43,6 & 1411,77 & 1049,44 & 1899,22 \\
\hline & $\Sigma=399,9$ & $\Sigma=\mathbf{2 9 6 , 8}$ & & & $\Sigma=9644,395$ & $\Sigma=9343,911$ & $\Sigma=15353,998$ \\
\hline
\end{tabular}
krotomografu rentgenowskiego. W tablicy 6 zawarte jest zestawienie danych obliczeniowych z przeprowadzonej korelacji.

- $\quad$ wartości średnie: $\bar{x}=13,4 ; \bar{y}=37,5$

- po podstawieniu do wzorów:

$$
\begin{gathered}
\operatorname{cov}(x, y)=\frac{56,21}{4}=8,0301 \\
S d_{x}=\sqrt{\frac{138,33}{4}}=4,45 \\
S d_{y}=\sqrt{\frac{30,33}{4}}=2,08 \\
r_{x, y}=\frac{8,0301}{4,45 \cdot 2,08}=0,8678 \\
r=0,87 \in<0,8 ; 0,8) \\
W D=(0,8678)^{2} \cdot 100 \% \\
\underline{W D=75,3 \%}
\end{gathered}
$$

Tablica 6. Dane obliczeniowe z korelacji procentowych udziałów objętości porów uzyskanych z badań za pomocą porozymetru rtęciowego oraz mikrotomografu rentgenowskiego

$x_{i}$ - procentowe udziały objętości poszczególnych porów z porozymetrii rtęciowej,

$y_{i}$ - procentowe udziały liczby podgrup należących do danej klasy objętościowej z mikrotomografii rentgenowskiej. 
Również podczas interpretacji wartości porowatości występuje bardzo wysoka dodatnia korelacja pomiędzy analizowanymi cechami. Wzrostowi porowatości porozymetrycznej towarzyszy wzrost wartości porowatości mikrotomograficznej (dane obliczeniowe w tablicy 7).

Na podstawie przeprowadzonej analizy korelacyjnej wyników uzyskanych przy zastosowaniu dwóch metod badawczych można zauważyć dopasowanie liniowej regresji dla obydwu metod. Otrzymano wartość liniowej regresji $R^{2}$ na poziomie 0,65 (rysunek 3 ). Również porównanie wartości porowatości uzyskanych z obydwu urządzeń skutkuje uzyskaniem wartości regresji liniowej na poziomie 0,75 (rysunek 4).
Wykonana analiza korelacyjna pozwala wnioskować, iż pomimo występującej różnicy w wartościach otrzymanych za pomocą obu metod badawczych (porozymetria rtęciowa oraz mikrotomografia rentgenowska) obserwowany jest porównywalny trend wzrostowy w interpretowanym zakresie. Należy jednak pamiętać, aby podczas porównywania wyników badań procentowych udziałów wielkości porów nie uwzględniać pustych przestrzeni o najmniejszych wymiarach, czyli porów mniejszych od około 6 mikrometrów. Jak już wcześniej wspomniano, ograniczenie spowodowane jest zakresem stosowalności mikrotomografu rentgenowskiego.

Tablica 7. Dane obliczeniowe z korelacji porowatości uzyskanych z badań za pomocą porozymetru rtęciowego oraz mikrotomografu rentgenowskiego

\begin{tabular}{|c|c|c|c|c|c|c|c|}
\hline Lp. & $x_{i}$ & $y_{i}$ & $\left(x_{i}-\bar{x}\right)$ & $\left(y_{i}-\bar{y}\right)$ & $\left(x_{i}-\bar{x}\right)\left(y_{i}-\bar{y}\right)$ & $\left(x_{i}-\bar{x}\right)^{2}$ & $\left(y_{i}-\bar{y}\right)^{2}$ \\
\hline 1 & 7,6 & 37,04 & $-5,8$ & $-0,5$ & 2,73 & 33,35 & 0,22 \\
\hline 2 & 15,4 & 38,35 & 2,0 & 0,8 & 1,70 & 4,10 & 0,70 \\
\hline 3 & 22,1 & 41,16 & 8,7 & 3,6 & 31,82 & 76,13 & 13,30 \\
\hline 4 & 8,4 & 33,50 & $-5,0$ & $-4,0$ & 19,96 & 24,75 & 16,10 \\
\hline & $\Sigma=\mathbf{5 3 , 5}$ & \multicolumn{7}{|c|}{$\Sigma=\mathbf{1 5 0 , 5}$} & & $\Sigma=\mathbf{5 6 , 2 1}$ & $\Sigma=\mathbf{1 3 8 , 3 3}$ & $\Sigma=\mathbf{3 0 , 3 3}$ \\
\hline
\end{tabular}

$x_{i}$ - wartości porowatości mikrotomograficznej, $y_{i}$ - wartości porowatości porozymetrycznej.

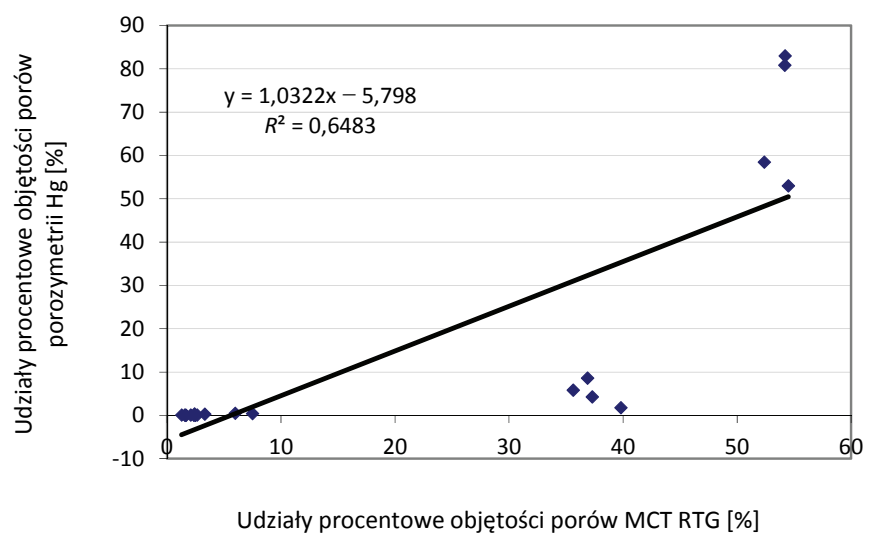

Rys. 3. Zależność udziału procentowego objętości porów uzyskana $\mathrm{z}$ badania za pomocą mikrotomografii rentgenowskiej oraz porozymetrii rtęciowej

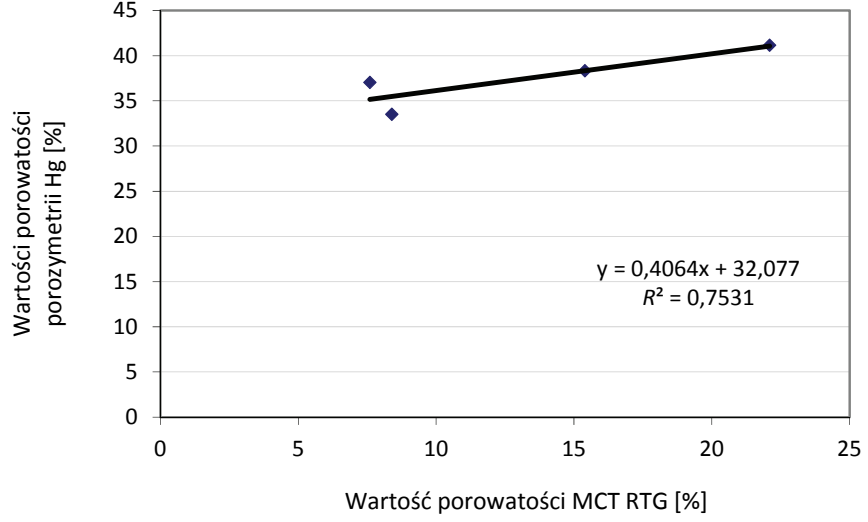

Rys. 4. Zależność wartości porowatości uzyskana $\mathrm{z}$ badania za pomocą mikrotomografii rentgenowskiej oraz porozymetrii rtęciowej

\section{Podsumowanie}

Przeprowadzona korelacja uzyskanych wyników badań przyczynia się do rozpoznania jakości i dokładności danej metodologii badawczej. Porównanie wyników badań umożliwia dokonanie wyboru metody odpowiedniej do danego cyklu badawczego. Dzięki temu możliwe jest też uzyskanie najbardziej reprezentatywnych wyników badań.

Na podstawie powyższej analizy otrzymano bardzo wysoką dodatnią korelację wyników uzyskanych z obu metod badawczych. Współczynniki korelacji Pearsona na pozio- mie 0,81 i 0,87 oraz odpowiadające im wskaźniki determinacji liniowej $(W D)$ rzędu 64,8\% i 75,3\% świadczą o bardzo dużej współzależności w wytypowanych zakresach interpretowanych wyników.

Należy jednak nadmienić, iż omawiane metody różni zakres pomiarowy, który - jak już wspomniano - zależy od procedury badawczej samego urządzenia. W związku z tym większy zakres porowatości możliwy jest do opisania za pomoca porozymetrii rtęciowej (jednakże w tej metodzie nie ma moż- 
liwości wizualizacji struktury przestrzennej badanej próbki). Pomiar porowatości opisywany za pomocą mikrotomografii rentgenowskiej cechuje się mniejszą dokładnością wyników, ponieważ nie ma możliwości zbadania porów o wielkości mniejszej niż 5,7 mikrometra. Jednak graficzne przedstawienie występujących porów pozwala zaklasyfikować tę metodę jako uzupełnienie pomiarów porozymetrycznych. Analiza parametrów mikrostruktury stwardniałego zaczynu umożliwia modyfikację receptur w celu uzyskania bardziej skompaktowanego płaszcza cementowego, a to z kolei przekłada się na znaczną poprawę efektywności uszczelnienia przestrzeni pierścieniowej. Na jakość kształtującej się mikrostruktury stwardniałego zaczynu uszczelniającego największy wpływ mają takie parametry jak porowatość i przepuszczalność.

Prowadzone badania porowatości umożliwiają rozpoznanie zależności zachodzących w mikrostrukturze stwardniałego zaczynu cementowego, dzięki czemu możliwe jest projektowanie nieprzepuszczalnych, maksymalnie skompaktowanych i charakteryzujących się niską porowatością stwardniałych zaczynów cementowych.

\section{Prosimy cytować jako: Nafta-Gaz 2016, nr 12, s. 1076-1083, DOI: 10.18668/NG.2016.12.10}

Artykuł nadesłano do Redakcji 29.06.2016 r. Zatwierdzono do druku 5.10.2016 r.

Artykuł powstał na podstawie pracy badawczej pt. Badania przestrzeni porowej stwardniałych zaczynów cementowych przeciwdziałajacych migracji gazu za pomoca mikrotomografii rentgenowskiej - praca INiG - PIB na zlecenie MNiSW, nr archiwalny: DK-4100/71/12, nr zlecenia: 71/KW/12 oraz pracy doktorskiej pt. Ograniczenie ekshalacji gazu w otworach wiertniczych poprzez modyfikację receptur oraz kształtowanie się struktury stwardniatych zaczynów uszczelniajacych; promotor: prof. dr hab. inż. Stanisław Stryczek; autor: dr inż. Marcin Kremieniewski.

\section{Literatura}

[1] Bonett A., Pafitis D.: Getting to the Root of Gas Migration. Oilfield Review, Spring 1996.

[2] Dębińska E.: Wyznaczanie statycznej wytrzymałości strukturalnej $i$ wczesnej wytrzymatości mechanicznej zaczynów cementowych. Nafta-Gaz 2013, nr 2, s. 134-142.

[3] Dohnalik M., Zalewska J.: Korelacja wyników badań laboratoryjnych uzyskanych metoda rentgenowskiej mikrotomografi, jadrowego rezonansu magnetycznego i porozymetrii rteciowej. Nafta-Gaz 2013, nr 10, s. 735-743.

[4] Kremieniewski M.: Ocena przepuszczalności kamieni cementowych pod katem ograniczenia migracji gazu. Prace Naukowe Instytutu Nafty i Gazu - PIB 2014, nr 196.

[5] Kremieniewski M.: Wpływ warunków hydratacji na strukture przestrzenna kamieni cementowych. Nafta-Gaz 2013, nr 1, s. $51-56$.

[6] Kremieniewski M., Rzepka M., Stryczek S., Wiśniowski R., Kotwica Ł., Złotkowski A.: Korelacja przepuszczalności i parametrów opisujacych strukturę stwardniałych zaczynów cementowych stosowanych do uszczelniania otworów $w$ rejonie Basenu Pomorskiego. Nafta-Gaz 2015, nr 10, s. 737-746, DOI: $10.18668 /$ NG2015.10.04.

[7] Kremieniewski M., Stryczek S., Kotwica Ł.: Zmiany w mikrostrukturze plaszcza cementowego w zależności od warunków hydratacji zaczynu. Nafta-Gaz 2014, nr 12, s. 918-926.

[8] Neville A.M.: Właściwości betonu. Kraków, Polski Cement, 2012.

[9] Stryczek S., Gonet A.: Kierunki ograniczania migracji gazu z przestrzeni pierścieniowej otworu wiertniczego. WUG: bez-

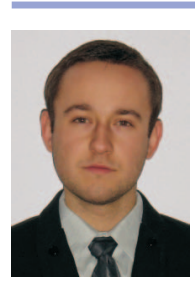

Dr inż. Marcin KREMIENIEWSKI

Adiunkt w Zakładzie Technologii Wiercenia.

Instytut Nafty i Gazu - Państwowy Instytut Badawczy

ul. Lubicz 25 A

31-503 Kraków

E-mail: marcin.kremieniewski@inig.pl

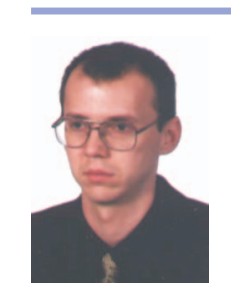

Dr inż. Marcin RZEPKA

Kierownik Laboratorium Zaczynów Uszczelniających w Zakładzie Technologii Wiercenia.

Instytut Nafty i Gazu - Państwowy Instytut Badawczy

ul. Lubicz 25 A

31-503 Kraków

E-mail: marcin.rzepka@inig.pl 